\title{
The potential of Eucalyptus plantations to restore degraded soils in semi-arid Morocco (NW Africa)
}

\author{
Mohamed Boulmane ${ }^{1}$ (D) Hayat Oubrahim ${ }^{2}$ - Mohammed Halim ${ }^{2} \cdot$ Mark R. Bakker $^{3}$. \\ Laurent Augusto ${ }^{3}$
}

Received: 9 September 2016 / Accepted: 13 June 2017 / Published online: 26 July 2017

(C) INRA and Springer-Verlag France SAS 2017

\begin{abstract}
- Key message Short-rotation forestry using eucalyptus in degraded oak forests in the semi-arid area of NW Morocco can be a useful strategy to avoid further degradation and carbon loss from this ecosystem, but it might be constrained by nutrient and water supply in the long term.
\end{abstract}

\section{Handling editor: Shuqing Zhao}

Contribution of the co-authors MB initiated the study. MB, LA and $\mathrm{MRB}$ designed it. MB and $\mathrm{HO}$ collected the data. All co-authors contributed to laboratory analyses and data interpretation. MB and LA wrote the first version of the manuscript, and all co-authors contributed to subsequent versions.

Electronic supplementary material The online version of this article (doi:10.1007/s13595-017-0652-z) contains supplementary material, which is available to authorized users.

Mohamed Boulmane

boulmanem@yahoo.fr

Hayat Oubrahim

h.oubrahim@gmail.com

Mohammed Halim

halimmohammed@gmail.com

Mark R. Bakker

mark.bakker@inra.fr

Laurent Augusto

laurent.augusto@inra.fr

1 Laboratoire de Pédologie, Centre de Recherche Forestière, B.P. 763, Av. Omar Ibn Khattab Agdal-Rabat, 10000 Rabat, Morocco

2 Faculté des Sciences, Université Mohammed V Agdal, 4 Av. Ibn Battouta, B.P. 1014, 10000 Rabat, RP, Morocco

3 Bordeaux Sciences Agro, INRA, UMR 1391 ISPA, F-33170 Gradignan, France
- Context Land degradation and deforestation of natural forests are serious issues worldwide, potentially leading to altered land use and carbon storage capacity.

- Aims Our objectives were to investigate if short-rotation plantations can restore carbon pools of degraded soils, without altering soil fertility.

- Methods Carbon and nutrient pools in above- and belowground biomass and soils were assessed using stand inventories, harvested biomass values, allometric relationships and selective sampling for chemical analyses.

- Results Carbon pools in the total ecosystem were low in the degraded land and in croplands $\left(6-13 \mathrm{Mg} \mathrm{ha}^{-1}\right)$ and high in forests (66-94 in eucalyptus plantations; 86-126innative forests). The soilnutrientstatus ofeucalyptusstands wasintermediate between degraded land and native forests and increased over time after eucalyptus introduction. All harvest scenarios for eucalyptus are likely to impoverish the soil but, for the moment, the soil nutrient status has notbeen affected.

- Conclusion Afforestation of degraded land with eucalyptus can be a useful restoration tool relative to carbon storage and soil fertility, provided that non-intensive forestry is applied.

Keywords Afforestation · Carbon pools $\cdot$ Soil nutrients · Cork oak · Eucalyptus

\section{Introduction}

Forest degradation and deforestation are well known for their negative impacts on the storage of organic carbon in the soil (Guo and Gifford 2002; Poeplau et al. 2011; Wei et al. 2014; Achat et al. 2015b). While these well-documented trends are representative of boreal, temperate and tropical regions, they hardly address semi-arid regions despite the surface area of dry forests at global scale (Bastin et al. 2017). For instance, in 
their recent meta-analysis, Wei et al. (2014) compiled data about deforestation and found that most case studies had a mean annual precipitation value, which was higher than 800-1000 mm year $^{-1}$. In addition, semi-arid regions are under high anthropic pressure (e.g. Vörösmarty and Sahagian 2000; Villamil et al. 2001; Sullivan and Rohde 2002; Seifan 2009). Consequently, there is a wide gap between expected impacts and available knowledge on soil carbon sequestration for dry regions. The main goal of our study was to quantify carbon pools in the semi-arid region of Kenitra, Morocco (NW Africa), hereby reducing this particular knowledge deficit.

In Morocco, deforestation has been a serious issue for decades and recently, the situation has become alarming. Currently, around 30,000 ha of native forests are lost annually (Benabid and Fennane 1999; F.R.A. 2015; Oubrahim 2015). These decreases have many causes, but most are pressures of human origin, such as excessive grazing, foliage harvest for cattle feeding, illegal charcoal production and illegal fuelwood and acorn harvest. All these activities have created areas of open degraded land (Oubrahim et al. 2016). In addition to woodland degradation, the surface area of native forests has diminished because of conversion to croplands that are dedicated to local food supply (Laouina et al. 2010). To cope with this situation, the Moroccan State initiated several plans aiming at restoring forest ecosystems, or just soil fertility (Laouina et al. 2010; Oubrahim 2015). As a first restoration attempt, re-creating hardwood forest is generally the objective. Alternatively, in the case of failure, or if wood production is locally lacking, state agencies sometimes install short-rotation plantations, which are based on fast-growing tree species: mainly eucalyptus but also pines or acacias. Our first objective was to quantify the capacity of short-rotation plantations to restore degraded soils or deforested areas. To do so, we studied carbon pools in four different types of land-use, representative of the semi-arid Moroccan context: (i) native oak forests, (ii) short-rotation plantations of eucalyptus, (iii) croplands for local food supply and (iv) degraded land. We used the soil content in organic carbon (SOC) as a proxy to evaluate the level of soil degradation because, in our context, soil organic carbon was negatively and linearly correlated with forest degradation (Oubrahim et al. 2016).

Because the use of eucalyptus species for intensive forestry is sometimes criticised for impoverishing soils (Michelsen et al. 1993; Tang et al. 2007; Leite et al. 2010; Chanie et al. 2013) due to their large nutrient requirements (e.g. Laclau et al. (2010), our second objective was to investigate the nutritive status under different land uses and to determine if eucalyptus management was compatible with maintenance of soil fertility. Our initial hypothesis was that short-rotation forestry based on eucalyptus could restore organic carbon pools of soils, but at the expense of soil fertility.

\section{Materials and methods}

\subsection{Study region and sites}

The region around Sidi Yahya-Gharb $\left(34^{\circ} 18^{\prime} 33^{\prime \prime} \mathrm{N}, 6^{\circ} 18^{\prime} 41^{\prime \prime}\right.$ $\mathrm{W})$ is a low-altitude plain ( $<18 \mathrm{~m}$ asl). The climate is semi-arid (mean annual precipitation, MAP $\approx 550 \mathrm{~mm} \mathrm{year}^{-1}$ ) with warm to hot temperatures (mean annual temperature, MAT $=15.8{ }^{\circ} \mathrm{C}$; monthly $\min$ and $\max =4.3$ and $36.5^{\circ} \mathrm{C}$ ). Rainfall usually occurs during the winter season. The upland soils of this region are sandy and acidic and are classified as Arenosols (FAO/IUSS 2006), which have developed in a deep sand layer $(0.85-3.20 \mathrm{~m})$. This sand layer was deposited over a clay-rich layer, hardly penetrable by plant root (Bellfontaine et al. 1979), which itself lies on calcareous sandstones.

In a preliminary step, we investigated the Sidi YahyaGharb region in order to identify sites representative of the four land uses (eucalyptus forest, cropland, native forest and degraded land) to be studied. Within a $15-\mathrm{km}$ radius around the city, we found nine sites which fulfilled our a priori criteria for selection (Online Resource 1), which were (1) at least 1 ha of homogeneous vegetation or land appearance, (2) similar soil physical properties among sites (all selected sites had same values of soil particle size distribution: clay $=2-3 \%$, silt $=2-3 \%$, sand $=90-95 \%$, stone $=0-4 \%$ ), (3) sufficient information about land management and (4) with the same land use for at least one decade. We found four eucalyptus stands (Eucalyptus camaldulensis Dehnh.), two croplands (non-irrigated cereals), two native stands (medium density stands of Quercus suber L., sensu Oubrahim et al. 2016) and one area of degraded land (formally native forest but currently nearly a desert area).

The eucalyptus stands represent a $\sim 48$-year chronosequence typical of the study region. Indeed, the first eucalyptuses are planted (1000 trees ha ${ }^{-1}$; the Euca-P1 stand in our study design) before being harvested at the age of 12 years old. Then, because eucalyptuses generally re-sprout after cutting, two successive coppice harvests are carried out every 12 years (stand Euca$\mathrm{C} 2$ at plantation date +24 years and Euca-C3 at plantation date +36 years). Finally, all trees (both above- and below-ground biomass) are harvested 12 years after the third re-sprout (Euca$\mathrm{C} 4$ at plantation +48 years), before a new 48 -year-long cycle is initiated by planting seedlings. Seedlings generally receive a single dose of fertilizer at planting (typically $30 \mathrm{~kg}-\mathrm{N} \mathrm{ha}^{-1}, 35 \mathrm{~kg}-\mathrm{P}$ $\mathrm{ha}^{-1}$ and $30 \mathrm{~kg}-\mathrm{K} \mathrm{ha}^{-1}$, once every 48 years).

Because of our strict selection criteria (see above), we had only two replicates of croplands, two native forests, only one degraded land and one eucalyptus chronosequence. Consequently, our study is a qualitative assessment of temporal trajectories, such as re-afforestation of degraded lands and not a statistical comparison of several land uses. Despite this statistical weakness, we consider our experimental design as representative of studied processes because carbon stock 
values of our degraded land and of native forests were close to analogues in a nearby region (Oubrahim et al. 2016).

\subsection{Tree sampling}

Because plant biomass was very low in the croplands and in the degraded land, this ecosystem compartment was considered as negligible in these sites and consequently, it was not measured. Indeed, in croplands, vegetation biomass is harvested each year and cannot accumulate in the long term, such as in forests. Similarly degraded lands are, in our study context, almost desert areas.

At each forest site, homogeneous areas representative of the stand were established as squares of 25-100 m aside, depending on stand configuration. In each square, all trees were measured, and basic statistics were performed (Online Resource 2). Intra-heterogeneity of stands was low to moderate, as shown by coefficient variation values of tree size (CV of circumference at breast height $(\mathrm{CBH}) 33-63 \%$ for eucalyptus stands, 30-31\% for native oak forests). Then, for native forests, we used published allometric relationships (Oubrahim et al. 2016) to derive tree biomass and carbon. For the eucalyptus stands, we built similar statistical models based on 71 trees (20 from Euca-P1 plantation; and $3 \times 17$ from coppiced stands Euca-C2 to EucaC4). For each tree, we measured tree height and stem circumference at breast height. We divided tree biomass into the following compartments: foliage + twigs, living branches, dead branches and stems. The proportion of wood and bark in stems was estimated from a sample of 19 completely debarked stems $\left(\%\right.$ bark $_{\text {weight }}=[-0.065 \times \mathrm{CBH}]+14.6$; respectively in $\%$ and $\left.\mathrm{cm} ; \mathrm{r}^{2}=0.94\right)$. The mass of each compartment was determined after drying. This procedure enabled us to calibrate allometric relationships for standing stems of E. camaldulensis (Online Resource 3). But, in the Sidi Yahya-Gharb region, eucalyptus stands are subject to illegal harvests. In practice, some stems are cut at the soil surface level. To quantify the amount of illegally harvested biomass, we thus built a relationship between circumference at topsoil level and circumference at breast height $\left(\mathrm{CBH}=\left[0.788 \times \mathrm{C}_{\text {stump }}\right]-2.34\right.$, in $\left.\mathrm{cm} ; \mathrm{r}^{2}=0.95\right)$. This relationship enabled us to estimate stem $\mathrm{CBH}$ and in turn the quantity of carbon exported by this kind of human pressure. Finally, we built allometric relationships for the root systems of coppiced trees (Euca-C4). Fifteen root systems (11 alive, 4 recently dead) were excavated, and the biomass of each stump and its adjacent coarse roots was exhaustively collected from $1.5 \mathrm{~m}$ around the stump to a depth of $1.0 \mathrm{~m}$. In addition, a volume of $3.5 \mathrm{~m}^{3}$ of soil for each root system was collected close to the stump and sieved to collect fine roots.

\subsection{Soil sampling}

For forest sites, soils were sampled in the square used for tree inventory. For croplands and degraded land, we chose a square of
$50 \mathrm{~m}$ aside that was visually representative of the whole site. Sampling was performed using 20 squares of one $\mathrm{m}^{2}$, distributed along transects located on a systematic grid. When an organic layer was present (i.e. in forest stands), the forest floor was sampled, sorted by hand (foliage, twigs + branches, bark), dried and weighed. The mineral soil of the nine sites was sampled systematically down to $100 \mathrm{~cm}$, from five layers: 0-20, 20-40, 40-60, 60-80 and 80-100 cm. Soil bulk density was determined for each layer using the cylinder method and based on four soil pits. The five layers of mineral soil were sampled as follows: 20 soil cores ( $1 \mathrm{~m}$ long) were collected from a systematic grid. For each soil layer, the 20 samples were mixed, and an aliquot was taken as a composite sample. Finally, each composite sample was sieved $(2 \mathrm{~mm})$ and dried to constant weight.

\subsection{Chemical analyses and calculations}

Stem disk samples rather than core samples, and actual values of nutrient concentrations rather than values from the literature, were used to ensure data reliability (Augusto and Bert 2005; Augusto et al. 2009). Plant samples - and forest floor samples - were ground before analysis. The following chemical determinations were performed: total carbon content $(\mathrm{C}$; by a combustion method) and total nitrogen content $(\mathrm{N}$; with $\mathrm{HCl}$ after Kjeldahl mineralisation $\left(\mathrm{H}_{2} \mathrm{SO}_{4}\right.$ with catalyst $\left.\mathrm{Se}\right)$ ). Mineralisation in aqua regia $\left(7.5 \mathrm{ml} \mathrm{HCl}+2.5 \mathrm{ml} \mathrm{HNO}_{3}\right)$ enabled the determination of $\mathrm{Ca}, \mathrm{Mg}$ and $\mathrm{K}$ by flame atomic absorption spectrometry (GBC 906A) and P by colorimetry using a phosphovanadomolybdate complex.

For the soil samples, the same elements $\left(\mathrm{C}_{\text {org }}, \mathrm{N}_{\text {total }}, \mathrm{P}_{\text {olsen }}\right.$, $\mathrm{K}_{\text {exch }}, \mathrm{Ca}_{\text {exch }}, \mathrm{Mg}_{\text {exch }}$ ) were analysed (Walkley and Black 1934; Olsen et al. 1954; Bremner 1960; Zhang et al. 2012). In practice, the organic $\mathrm{C}$ content was assessed by the acid oxidation method, the total $\mathrm{N}$ content by the Kjeldahl method, the available $\mathrm{P}$ content by extraction with $\mathrm{NaHCO}_{3}$ and the exchangeable cation content by the acetate ammonium method.

Stocks of elements were calculated, using biomass values and concentration values for plants and using the soil layer weight and concentration values for soils. We used these stocks to evaluate the impact of land-use changes on carbon pools (the first objective) and on soil fertility (the second objective). For carbon pools, we calculated an index of soil degradation. To do so, we used as reference the mean value of soil carbon stocks in dense, healthy, native forests (81.2 Mg-C $\mathrm{ha}^{-1}$ in the forest floor layer and in mineral soil layers; cf. Fig. 5 in Oubrahim et al. (2016)). The degradation index value was then calculated as follows:

Degradation index $=1-\left(\mathrm{SOC}_{\text {stand }}: \mathrm{SOC}_{\mathrm{ref}}\right)$

The index of soil degradation scales from 0 (i.e. no degradation of SOC stocks) to 1 (i.e. complete loss of SOC). 


\subsection{Scenarios of biomass harvest in eucalyptus forests and in native forests}

In a final step, in line with our second objective, we investigated which intensity of eucalyptus biomass harvest was likely to be the best compromise between a high rate of biomass removal and the maintenance of soil fertility. To do this, we estimated the quantities of biomass and elements exported from the ecosystems based on five harvest scenarios ( $\mathrm{S}$, SR100, SB, SBR80 and SBR100). Those scenarios were the result of different choices in terms of biomass harvest: $\mathrm{B}=$ stem bark is harvested with stem wood (i.e. no in situ debarking); R80 and R100 $=80$ or $100 \%$ of forest residues (here tree canopy) are harvested. In all scenarios, stem wood was harvested down to a diameter of $7 \mathrm{~cm}$ (S modality). In the study region, the SBR80 scenario is the usual practice.

In native oak forests, only the bark is exported. The average annual volume exported from the Mamora oak forest is 0.79 $1.41 \mathrm{~m}^{3} \mathrm{ha}^{-1}$ year. ${ }^{-1}$, depending on the years (HCEFLCD, Morocco: unpublished surveys). Bulk density values of bark piles are $90-150 \mathrm{~kg} \mathrm{~m}^{-3}$ (HCEFLCD). For export calculations, we assumed median values $\left(1.10 \mathrm{~m}^{3} \mathrm{ha}^{-1}\right.$ year $\left.^{-1} ; 120 \mathrm{~kg} \mathrm{~m}^{-3}\right)$, resulting in a median bark export of $132 \mathrm{~kg} \mathrm{ha}^{-1}$ year $^{-1}$.

\section{Results}

\subsection{Impact of land-use changes on carbon sequestration}

In forests, $\mathrm{C}$ concentrations in standing biomass were close to $500 \mathrm{mg} \mathrm{g}^{-1}$. Because there were no large differences in carbon concentrations (eucalyptus $=450-500 \mathrm{mg} \mathrm{g}^{-1}$; oak $=520$ $560 \mathrm{mg} \mathrm{g}^{-1}$ ), it was the difference between biomass values, driven themselves by stand dendrometry (Online Resource 2) that best explained the amounts of carbon sequestrated in trees (Online Resource 4). The standing above-ground biomass and its related carbon stock were of the same order of magnitude for all forest sites, with no clear differences between eucalyptus plantations and native oak forests. On the other hand, when exports were taken into account and not the standing biomass alone, the eucalyptus fixed two to four times more $\mathrm{C}$ during the 48-year-long revolution than native forests over the same duration $\left(\sim 113 \mathrm{Mg} \mathrm{ha}^{-1}\right)$.

The influence of land use on carbon sequestration was also quite clear in the soils. The degraded land and, to a lesser extent, croplands displayed the lowest values of soil carbon concentrations down to $60 \mathrm{~cm}$ (Fig. 1). Conversely, forest soils contained large amounts of organic carbon (34-75 $\mathrm{Mg} \mathrm{ha}^{-1}$; Table 1). It is worth highlighting the restorative influence of afforestation on degraded lands, even with short-rotation plantations such as eucalyptus plantations. Indeed, topsoil $(0-20 \mathrm{~cm})$ carbon concentrations increased gradually from eucalyptus plantation (EucaP1, planted on formerly degraded land) to Euca-C3 and Euca-
C4 stages, resulting in similar concentration values to those found in native forests (Fig. 1). The 20-40-cm layer demonstrated the same restorative pattern, with carbon concentrations increasing with the age of the eucalyptus plantation. In contrast to the topsoil layer, carbon concentrations of the 20-40-cm layer remained lower in eucalyptus forests than in native forests, even in the Euca-C4 soil (Fig. 1). In our context, planting eucalyptus trees on degraded land led to an increase in the soil carbon pool of $2.4 \mathrm{Mg} \mathrm{ha}^{-1}$ year $^{-1}$ during the first rotation (calculated as the difference between Euca-P1 and Degraded-9) and 0.8-1.4 Mg $\mathrm{ha}^{-1}$ year $^{-1}$ afterwards (from Euca-P1 to Euca-C4). Hence, values of our index of soil degradation progressively decreased during eucalyptus rotations (from 0.58 down to 0.08 ; Table 1 ), while this index value was 0.93 in the degraded land.

\subsection{Soil nutritive status and possible impact of eucalyptus forestry}

In a second step, we investigated whether changes in land use had an impact on soil fertility. The fertilisation regime in croplands was clearly visible with an accumulation of phosphorus, potassium and magnesium in the deep soil layers (Fig. 1). The degraded land had the poorest soil in terms of total nitrogen and available forms of phosphorus and calcium (Fig. 1). Conversely, soils under native forest often displayed the highest values of nutrient concentrations, especially in the topsoil layer. Soils under eucalyptus stands were intermediate: in the topsoil, afforestation with eucalyptus had progressively increased the soil contents of total nitrogen, available phosphorus and calcium (Fig. 1). Although the pattern was less obvious for potassium and magnesium, it appeared that the nutritive status of soils after a few decades of eucalyptus presence (i.e. Euca-C3 and Euca-C4) was comparable with, or slightly lower than, those of native forest soils. In other words, eucalyptus growth had no visible negative impact on soil fertility.

In a final step, we evaluated the extent to which this soil pattern could be explained or not by eucalyptus forestry and harvest practices in particular. There were some differences in nutrient concentration between $Q$. suber and $E$. camaldulensis (Online Resource 5). However, because the amounts of biomass exported from native forests were extremely low, and much lower than exports from eucalyptus stands (Online Resource 4), such differences in nutrient concentration did not change the pattern imposed by the biomass values: eucalyptus forestry induced nutrient exports as a result of biomass harvests, which were much higher than those related to the management of native forests. In eucalyptus trees, values of nutrient concentrations in above-ground tissues could be ranked as follows (Online Resource 5): foliage $>$ twigs $\geq$ branches, bark $>$ wood. Stem wood represented a high proportion of tree biomass $(69 \%$, see harvest scenario $\mathrm{S}$ in Table $2 b$ ) but a lower proportion of tree mineral mass (35$66 \%$, Table $2 b$ ). Including in exports, stem bark (scenario SB) 
Fig. 1 Carbon and nutrient concentrations in the soil profiles. $C=\mathrm{C}_{\text {org }}, N=\mathrm{N}_{\text {total }}, P=\mathrm{P}_{\text {Olsen }}, K$, $\mathrm{Ca}$, and $\mathrm{Mg}=$ exchangeable cations, Euca- $P 1$ eucalyptus plantation, Euca-C2, Euca-C3, and Euca-C4 coppiced eucalyptus stands (2nd, 3rd and 4th rotations), Crop-5 and Crop-6 croplands, Quercus-7 and Quercus-8 native oak forests, Degraded-9 degraded land (formally a native forest). Graphic program used: Excel-2010
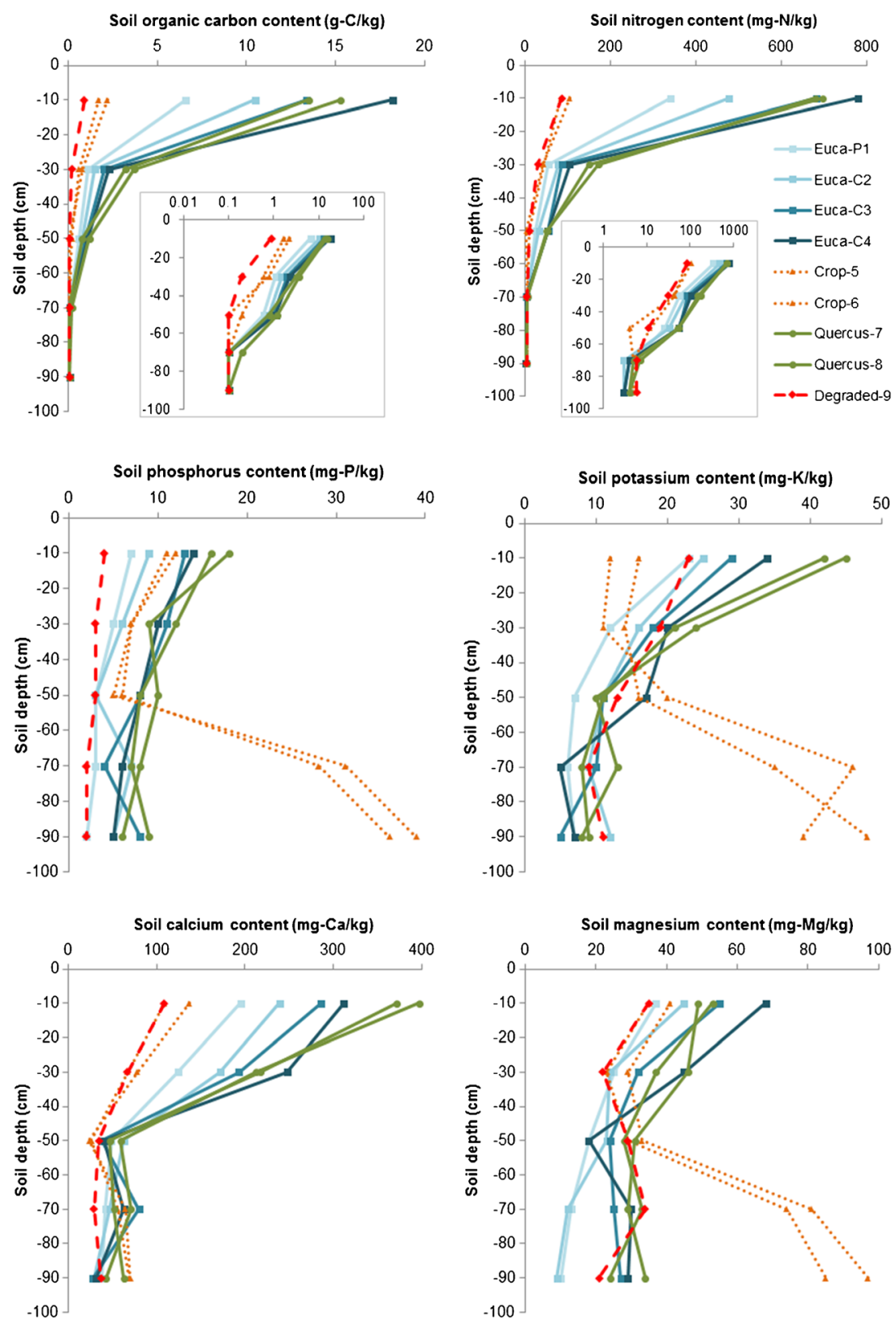

and, above all, harvest residues (scenarios SR100, SBR80 and SBR100) resulted in a small gain in biomass harvest but in large additional losses of nutrients (Table 2). Nutrient exports induced by the most intensive scenario (SBR100) were 653, 107, 993, 2188 and $196 \mathrm{~kg} \mathrm{ha}^{-1}$ of $\mathrm{N}, \mathrm{P}, \mathrm{K}, \mathrm{Ca}$ and $\mathrm{Mg}$, respectively (Table 2a). The possible impact of the SBR80 scenario, which is the usual practice in our study region, was similar to that of the SBR100 scenario. These intensive outputs (SBR80 or SBR100) were of the same order of magnitude as the nutrient pools in the Euca-C4 soil (Table 2c). The similarity between nutrient exports by actual (SBR80) biomass harvests on the one hand, and soil nutrient stocks on the other, leads to the conclusion that eucalyptus forestry is likely to impoverish soils. Fortunately, in our context, this has not been the case so far (Fig. 1), but an explanation for this discrepancy is necessary.

\section{Discussion}

\subsection{Carbon}

Afforestation with eucalyptus induced high rates of biomass and carbon accumulation. Eucalyptus plantations under tropical or temperate climates can grow even faster (Bargali et al. 1992b; Laclau et al. 2000; Du et al. 2015; González-García et al. 2015) but, taking into account the low fertility of the sandy soils and the semi-arid climate at this study site, such 
Table 1 Soil organic carbon (SOC) stocks for the ecosystems studied

\begin{tabular}{lccccccccc}
\hline $\begin{array}{l}\text { Carbon stocks } \\
\left(\mathrm{Mg} \mathrm{ha}^{-1}\right)\end{array}$ & $\begin{array}{l}\text { Euca- } \\
\text { P1 }\end{array}$ & $\begin{array}{l}\text { Euca- } \\
\text { C2 }\end{array}$ & $\begin{array}{l}\text { Euca- } \\
\text { C3 }\end{array}$ & $\begin{array}{l}\text { Euca- } \\
\text { C4 }\end{array}$ & $\begin{array}{l}\text { Crop- } \\
5\end{array}$ & $\begin{array}{l}\text { Crop- } \\
6\end{array}$ & $\begin{array}{l}\text { Quercus- } \\
7\end{array}$ & $\begin{array}{l}\text { Quercus- } \\
8\end{array}$ & $\begin{array}{l}\text { Degraded- } \\
9\end{array}$ \\
\hline Forest floor & 0.95 & 1.10 & 1.31 & 1.52 & 0.23 & 0.17 & 1.94 & 3.61 & 0.09 \\
$0-20 \mathrm{~cm}$ & 25.1 & 38.1 & 45.0 & 59.6 & 6.29 & 8.62 & 44.0 & 50.8 & 3.56 \\
$20-40 \mathrm{~cm}$ & 4.31 & 5.76 & 7.49 & 8.70 & 2.30 & 3.01 & 10.5 & 14.2 & 0.81 \\
$40-60 \mathrm{~cm}$ & 2.45 & 3.25 & 3.96 & 4.37 & 0.83 & 0.42 & 3.06 & 4.39 & 0.43 \\
$60-80 \mathrm{~cm}$ & 0.85 & 0.42 & 0.42 & 0.43 & 0.43 & 0.43 & 0.42 & 0.82 & 0.45 \\
$80-100 \mathrm{~cm}$ & 0.43 & 0.44 & 0.43 & 0.42 & 0.41 & 0.44 & 0.42 & 0.42 & 0.43 \\
Total SOC & 34.1 & 49.0 & 58.6 & 75.0 & 10.5 & 13.1 & 60.4 & 74.3 & 5.77 \\
Index of soil & 0.58 & 0.40 & 0.28 & 0.08 & 0.87 & 0.84 & 0.26 & 0.09 & 0.93 \\
$\quad$ & & & & & & & & \\
\hline
\end{tabular}

The index of soil degradation scales from 0 (i.e. no degradation of SOC stocks) to 1 (i.e. complete loss of SOC). This index was calculated based on properties of similar soils of the same regions and cannot consequently be used in another context (see Sect. 2 for details)

Euca-P1 eucalyptus plantation, Euca-C2, Euca-C3, and Euca-C4 coppiced eucalyptus stands (2nd, 3rd, and 4th rotations), Crop-5 and Crop-6 croplands, Quercus-7 and Quercus- 8 native oak forests, Degraded-9 degraded land (formally a native forest) growth rates were remarkably high. This was particularly the case for below-ground biomass with a root/shoot ratio above six. Under temperate to subtropical climates, the root/shoot ratio is typically between two and three (Herrero et al. 2014; Vega-Nieva et al. 2015; Salomon et al. 2016) but may increase

Table 2 Exports of biomass and nutrients from eucalyptus stands under different harvest scenarios

\begin{tabular}{|c|c|c|c|c|c|c|}
\hline & Biomass & $\mathrm{N}$ & $\mathrm{P}$ & $\mathrm{K}$ & $\mathrm{Ca}$ & $\mathrm{Mg}$ \\
\hline \multicolumn{7}{|c|}{ a. Biomass $\left(\mathrm{Mg} \mathrm{ha}^{-1}\right)$ and mineral mass $\left(\mathrm{kg} \mathrm{ha}^{-1}\right)$} \\
\hline $\mathrm{S}(\mathrm{S} 1)$ & 143 & 246 & 55 & 660 & 775 & 68 \\
\hline SR100 (S2) & 188 & 601 & 99 & 934 & 1420 & 144 \\
\hline SB (S3) & 162 & 299 & 63 & 718 & 1543 & 120 \\
\hline SBR80 (S4) & 198 & 582 & 98 & 938 & 2059 & 181 \\
\hline SBR100 (S5) & 207 & 653 & 107 & 993 & 2188 & 196 \\
\hline \multicolumn{7}{|c|}{ b. Biomass and mineral mass ( $\%$ of standing stocks) } \\
\hline $\mathrm{S}(\mathrm{S} 1)$ & 69 & 38 & 51 & 66 & 35 & 35 \\
\hline SR100 (S2) & 91 & 92 & 93 & 94 & 65 & 73 \\
\hline SB (S3) & 78 & 46 & 59 & 72 & 71 & 61 \\
\hline SBR80 (S4) & 96 & 89 & 92 & 94 & 94 & 92 \\
\hline SBR100 (S5) & 100 & 100 & 100 & 100 & 100 & 100 \\
\hline \multicolumn{7}{|c|}{$\begin{array}{l}\text { c. Nutrient stocks in soil for the eucalyptus stands before biomass harves } \\
\left(\mathrm{kg} \mathrm{ha}^{-1} ; 0-100 \mathrm{~cm} \text { soil layer }\right)\end{array}$} \\
\hline Euca-P1 & & 1665 & 80 & 219 & 1771 & 411 \\
\hline Euca-C2 & & 2195 & 119 & 288 & 2112 & 439 \\
\hline Euca-C3 & & 2869 & 167 & 271 & 2287 & 619 \\
\hline Euca-C4 & & 3195 & 162 & 305 & 2524 & 713 \\
\hline
\end{tabular}

Eucalyptus stands: four rotations of 12 years (one plantation, followed by three coppiced stands)

Euca-P1 eucalyptus plantation, Euca-C2, Euca-C3, and Euca-C4 coppiced eucalyptus stands (2nd, 3rd, and 4th rotations), $S$ stem wood (stems with circumference at breast height $>7 \mathrm{~cm}$ ) harvested, $B$ stem bark harvested, $R 80$ and $R 10080$ or $100 \%$ of harvesting residues exported to almost six for coppiced stands (Razakamanarivo et al. 2012). Hence, even if it is difficult to quantify root biomass in a reliable way (Ritson and Sochacki 2003; Danjon and Reubens 2008; Augusto et al. 2015), our root/shoot value was plausible and may be the consequence of a high allocation of resources to their roots by coppiced trees (Zadworny et al. 2014) under a dry climate (Canadell et al. 1996). Eucalyptus trees have deep root systems (Laclau et al. 2001; Christina et al. 2011; Pinheiro et al. 2016), so we assume that coppiced eucalyptus trees under dry conditions could exhibit exceptionally high values of root/shoot ratios. In practice, in the region studied, eucalyptus roots are harvested after the final Euca-C4 rotation for local needs (i.e. fuel wood for heating hamams) and villagers frequently cut above-ground biomass of eucalyptus for their domestic needs. Therefore, in addition to the possible use of eucalyptus biomass for the production of paper pulp, and even if some cuts were illegal, we speculate that eucalyptus forestry could reduce the anthropic pressure on native oak forests (Oubrahim 2015).

Similarly to carbon in standing plants, afforestation is well known to substantially increase stocks of soil organic carbon (SOC) when starting from croplands or degraded land (Singh et al. 2000; Paul et al. 2002; Nogueira et al. 2006; Poeplau et al. 2011; Li et al. 2012; Barcena et al. 2014). Our study agreed perfectly with this global pattern, with forest soils being up to one order of magnitude richer in carbon than croplands or degraded land. What was rather surprising was the rapidity of the restoration of SOC pools of degraded land induced by eucalyptus forestry (i.e. $0.8-2.4 \mathrm{Mg} \mathrm{ha}^{-1}$ year $^{-1}$ ) because, even if plantations with species of the Eucalyptus genus are generally good at storing organic carbon in soils (Li et al. 2012; Boca et al. 2014), this is far from being always the case (Du et al. 2015; Hernández et al. 2016b). We explain such a high rate of SOC accumulation as a consequence of the 
initial SOC pool in degraded land. Based on a large survey of eucalyptus stands in Brazil, Cook et al. (2016) have shown that the effect of eucalyptus plantation depended primarily and negatively on the initial SOC stock: afforestation with eucalyptus caused an increase, no change, or even a decrease when the initial SOC stock was below, equal to or above $\sim 20-40 \mathrm{Mg}$ $\mathrm{ha}^{-1}$ in the $0-30-\mathrm{cm}$ soil layer (see Fig. 4 in Cook et al. (2016)). With a SOC stock of $\sim 4 \mathrm{Mg} \mathrm{ha}^{-1}$ in the $0-30-\mathrm{cm}$ soil layer, our degraded site was expected to accumulate 1.0 $1.5 \mathrm{Mg} \mathrm{ha}^{-1}$ year $^{-1}$ of SOC due to eucalyptus afforestation. This expectation, based on Brazilian eucalyptus stands, was consistent with our Moroccan results $(0.8-2.4 \mathrm{Mg}$ $\mathrm{ha}^{-1}$ year $\left.^{-1}\right)$. The SOC accumulation was mainly observed in top-soil and mid-soil layers, suggesting that both the litterfall flux $\left(\approx 2.2 \mathrm{Mg} \mathrm{ha}^{-1}\right.$ year $^{-1}$ at 12 years, Boulmane, unpublished data; see Turner and Lambert (2016) for comparison) and the fine roots have contributed to SOC stabilisation (Clemmensen et al. 2013; Hatton et al. 2015).

All in all, we conclude that planting fast-growing eucalyptus is a winning strategy to restore SOC pools of degraded, mineral, arenosols in semi-arid areas of Morocco. Nevertheless, despite being an important ecosystem service provided by soils, carbon sequestration is not the only one and others exist, such as soil fertility, soil biodiversity or nutrient cycling (Nogueira et al. 2006; Adhikari and Hartemink 2016). Because negative effects of eucalyptus forests are recurrently reported in the literature (e.g. Ferreira et al. 2016; Leite et al. 2010; Michelsen et al. 1993; Nogueira et al. 2006), we also evaluated the extent to which eucalyptus afforestation may alter the soil nutrient status in our study region.

\subsection{Soil fertility}

Although deforestation for crop production clearly reduced SOC pools (this study; see Wei et al. (2014) for a larger perspective), this was not the case for nutrients such as $\mathrm{K}, \mathrm{P}$ and $\mathrm{Mg}$ (Fig. 1), likely as a result of fertiliser application in croplands. The vertical distribution of calcium was an exception that might be the consequence of the absence of liming practices in local agriculture.

Our initial expectation was that afforestation of degraded land with a nutrient demanding species, such as E. camaldulensis, could lead to more soil degradation (Leite et al. 2010). However, on the contrary, the contents of total $\mathrm{N}$ and available forms of $\mathrm{P}, \mathrm{K}, \mathrm{Ca}$ and $\mathrm{Mg}$ in the soil were progressively improved by eucalyptus forestry (see Nogueira et al. 2006 and Jeddi et al. 2009 for similar trends). Because atmospheric nitrogen deposition is quite low in the study region (Lamarque et al. 2005), we assumed that the increase of $\mathrm{N}$ in the ecosystem pool was due to asymbiotic (Reed et al. 2011) and symbiotic $\mathrm{N}_{2}$ fixation. The local presence of $\mathrm{N}$ fixing shrubs (i.e. Genista linifolia, formally named Teline linifolia; Oubrahim et al. 2016) and high rates of fixation of plants growing in poor soils (Augusto et al. 2005) such as in our context (Hracherrass et al. 2013) support the idea that symbiotic $\mathrm{N}_{2}$ fixation was partly responsible for the effect of afforestation on soil $\mathrm{N}$ dynamics.

The increase of the soil pool of exchangeable $\mathrm{K}, \mathrm{Ca}$ and $\mathrm{Mg}$ was unexpected (Berthrong et al. 2009) but could be explained by two processes. First, in sandy forest soils, most of the soil cation exchange capacity (CEC) is due to the presence of organic matter (Turpault et al. 1996; Johnson 2002; Augusto et al. 2010). As afforestation improved the SOC content, it probably increased soil CEC and, in turn, the pools of exchangeable cations (Cook et al. 2016). A second explanation, which is not in contradiction with the one based on CEC, is related to tree rooting depth. Roots of eucalyptus species can penetrate to great depths: down to $10 \mathrm{~m}$ and probably even deeper (Laclau et al. 2001; Christina et al. 2011; Pinheiro et al. 2016). In our study region, arenosols rely on deep clay-rich or calcareous layers (cf. Materials and Methods), which are likely to contain substantial amounts of cation- and P-bearing minerals (phyllosilicates, feldspars, carbonates, apatites, etc.). It is therefore possible that eucalyptus trees have developed root systems to access these layers and that they have been able to take up K, $\mathrm{Ca}$ and $\mathrm{Mg}$ from them. With this idea in mind, trees could be seen as biological pumps, lifting nutrients from deep soil layers to the topsoil by root uptake, allocation to foliage and finally litterfall. The same reasoning could apply to the available phosphorus soil pool. In addition, afforestation of degraded land may have improved soil $\mathrm{P}$ status, particularly by increasing organic forms of available P (De Schrijver et al. 2012). To sum up, as opposed to our initial hypothesis (see Lemenih et al. 2004; Berthrong et al. 2009 and Temesgen et al. 2016 for negative effects of afforestation), planting eucalyptus in degraded land has not impaired soil fertility but has improved it.

A comparison of the foliage nutrient contents of our study with other eucalyptus species throughout the world showed that our results were in the same range, or sometimes slightly higher (N, P, Ca), than in other contexts (Bargali et al. 1992a; Hopmans et al. 1993; González-García et al. 2015; Gomez-Garcia et al. 2016; Hernández et al. 2016a; Turner and Lambert 2016), suggesting that the eucalyptus stands of our study were not severely nutrient stressed. However, taking into account (i) the high demand for nutrients of eucalyptus species (Laclau et al. 2003; Laclau et al. 2010) and (ii) the intrinsically low resilience of arenosols, we considered that nutrient outputs due to forest management may reduce soil fertility in the long term. Because intensive harvests have been shown to be detrimental to SOC pools (Achat et al. 2015b) and to ecosystem functioning (Achat et al. 2015a; Rocha et al. 2016), intensive management of eucalyptus remains questionable in semi-arid Morocco. That is why, we suggest that foliage - a compartment rich in nutrients (Augusto et al. 2008) — should not be exported from eucalyptus stands, because this kind of cropping has the highest environmental impact (Achat et al. 2015a; Augusto et al. 2015). 
In addition to soil fertility, water supply remains a source of concern because eucalyptus species are known for their capability to forage water deeply and consequently to negatively impact river fluxes (Poore and Fries 1986). It is particularly the case in dry regions such as in the Gharb region, where our study took place. On the other hand, eucalyptus plantations may have also positive effects in our context, especially during the winter season. Indeed, in the Gharb region (dominated by croplands and degraded lands), lowlands (dominated by vertisols; Billaux and Bryssine 1967) can be flooded because heavy rains cannot completely infiltrate soils of uplands, with low vegetation cover (Lakrikba 2015). Because eucalyptus plantations probably reduce water run-offs and severity of winter floods, an assessment of their impact on water fluxes and stocks is necessary.

\section{Conclusion}

Our qualitative investigation has suggested that short-rotation forestry using eucalyptus can be a useful tool for restoring degraded land, both in terms of carbon sequestration and soil fertility. Nevertheless, our study lacked site replicates, and the extent to which local soils can support intensive eucalyptus production in the long term is unknown. That is why, despite their positive effects at present, we conclude that eucalyptus afforestation should be further assessed before promoting this kind of shortrotation forestry as being the best solution in semi-arid, degraded forests. Meanwhile, applying non-intensive harvest scenarios in existing eucalyptus stands and preserving the remaining native forests seem to be the most sustainable options.

Acknowledgements We are grateful to the technical staffs of the HCEFLCD, and of the INRA, for their support during the sampling campaigns and the laboratory work. Field sampling and laboratory analyses were carried out by Amrani Abdessamad, Aziz Khraouch and Bounimi Zhor. We also thank all CRF staff for their support. Our thanks also go to Campus France, the Moroccan State and the French State which funded our collaboration project. We are grateful to the bilateral project between France and Morocco PRAD 18 for the financial support, permitting an exchange of staff and constructive work sessions. Finally, we thank two anonymous reviewers and members of the editorial board who greatly improved this manuscript through their constructive comments.

\section{Compliance with ethical standards}

Funding This study was partly funded by the bilateral project between France and Morocco PRAD 01/13 "Projet de Recherche Agronomique pour Developpement",

\section{References}

Achat DL, Deleuze C, Landmann G, Pousse N, Ranger J, Augusto L (2015a) Quantifying consequences of removing harvesting residues on forest soils and tree growth - a meta-analysis. For Ecol Manag 348:124-141. doi:10.1016/j.foreco.2015.03.042

Achat DL, Fortin M, Landmann G, Ringeval B, Augusto L (2015b) Forest soil carbon is threatened by intensive biomass harvesting. Sci Rep 5:15991. doi:10.1038/srep15991

Adhikari K, Hartemink AE (2016) Linking soils to ecosystem servicesa global review. Geoderma 262:101-111. doi:10.1016/j.geoderma. 2015.08.009

Augusto L, Bert D (2005) Estimating stemwood nutrient concentration with an increment borer: a potential source of error. Forestry 78: 451-455. doi:10.1093/forestry/cpi041

Augusto L, Crampon N, Saur E, Bakker MR, Pellerin S, de Lavaissiere C, Trichet P (2005) High rates of nitrogen fixation of Ulex species in the understory of maritime pine stands and the potential effect of phosphorus fertilization. Can J For Res 35:1183-1192. doi:10.1139/ x05-054

Augusto L, Meredieu C, Bert D, Trichet P, Porte A, Bosc A, Lagane F, Loustau D, Pellerin S, Danjon F, Ranger J, Gelpe J (2008) Improving models of forest nutrient export with equations that predict the nutrient concentration of tree compartments. Ann For Sci 65. doi:10.1051/forest:2008059

Augusto L, Bakker MR, De Lavaissiere C, Jordan-Meille L, Saur E (2009) Estimation of nutrient content of woody plants using allometric relationships: quantifying the difference between concentration values from the literature and actuals. Forestry 82:463-477. doi:10. 1093/forestry/cpp019

Augusto L, Bakker MR, Morel C, Meredieu C, Trichet P, Badeau V, Arrouays D, Plassard C, Achat DL, Gallet-Budynek A, Merzeau D, Canteloup D, Najar M, Ranger J (2010) Is 'grey literature' a reliable source of data to characterize soils at the scale of a region? A case study in a maritime pine forest in southwestern France. Eur J Soil Sci 61:807-822. doi:10.1111/j.1365-2389.2010.01286.x

Augusto L, Achat DL, Bakker MR, Bernier F, Bert D, Danjon F, Khlifa R, Meredieu C, Trichet P (2015) Biomass and nutrients in tree root systems - sustainable harvesting of an intensively managed Pinus pinaster (Ait.) planted forest. Glob Change Biol Bioenergy 7:231243. doi:10.1111/gcbb.12127

Barcena TG, Kiaer LP, Vesterdal L, Stefansdottir HM, Gundersen P, Sigurdsson BD (2014) Soil carbon stock change following afforestation in northern Europe: a meta-analysis. Glob Chang Biol 20: 2393-2405. doi:10.1111/gcb.12576

Bargali SS, Singh RP, Singh SP (1992a) Structure and function of an age series of eucalypt plantations in central Himalaya.2. Nutrient dynamics. Ann Bot 69:413-421

Bargali SS, Singh SP, Singh RP (1992b) Structure and function of an age series of eucalypt plantations in central Himalaya.1. Dry-matter dynamics. Ann Bot 69:405-411

Bastin JF, Berrahmouni N, Grainger A, Maniatis D, Mollicone D, Moore R, Patriarca C, Picard N, Sparrow B, Abraham EM, Aloui K, Atesoglu A, Attore F, Bassuullu C, Bey A, Garzuglia M, GarciaMontero LG, Groot N, Guerin G, Laestadius L, Lowe AJ, Mamane B, Marchi G, Patterson P, Rezende M, Ricci S, Salcedo IH, Diaz ASP, Stolle F, Surappaeva V, Castro R (2017) The extent of forest in dryland biomes. Science 356:635-638

Bellfontaine R, Raggabi M, Nanson A (1979) Expérience internationale d'origines d'Eucalyptus camaldulensis dehn. Dispositif de Sidi Slimane (Maroc). Annales de Recherche Forestière du Maroc 19: 339-398

Benabid B, Fennane M (1999) Ecosystèmes forestiers: structure, beauté et diversité: principales formations forestières. In: Margada (ed) Le grand livre de la forêt marocaine. Sprimont, Belgique, pp 71-93

Berthrong ST, Jobbagy EG, Jackson RB (2009) A global meta-analysis of soil exchangeable cations, $\mathrm{pH}$, carbon, and nitrogen with afforestation. Ecol Appl 19:2228-2241. doi:10.1890/08-1730.1 
Billaux P, Bryssine G (1967) Soils of Morocco [in French]. Cahiers de la Recherche Agronomique 24:59-101

Boca A, Van Miegroet H, Gruselle MC (2014) Forest overstory effect on soil organic carbon storage: a meta-analysis. Soil Sci Soc Am J 78: S35-S47. doi:10.2136/sssaj2013.08.0332nafsc

Bremner JM (1960) Determination of nitrogen in soil by the Kjeldahl method. J Agric Sci 55:11-33

Canadell J, Jackson RB, Ehleringer J, Mooney HA, Sala OE, Schulze ED (1996) Maximum rooting depth of vegetation types at the global scale. Oecologia 108:583-595

Chanie T, Collick AS, Adgo E, Lehmann CJ, Steenhuis TS (2013) Ecohydrological impacts of eucalyptus in the semi humid Ethiopian highlands: the Lake tana plain. J Hydrol Hydromech 61:21-U107. doi:10.2478/johh-2013-0004

Christina M, Laclau JP, Goncalves JLM, Jourdan C, Nouvellon Y, Bouillet JP (2011) Almost symmetrical vertical growth rates above and below ground in one of the world's most productive forests. Ecosphere 2:art.27. doi:10.1890/Es10-00158.1

Clemmensen KE, Bahr A, Ovaskainen O, Dahlberg A, Ekblad A, Wallander H, Stenlid J, Finlay RD, Wardle DA, Lindahl BD (2013) Roots and associated fungi drive long-term carbon sequestration in boreal forest. Science 339:1615-1618. doi:10.1126/ science. 1231923

Cook RL, Binkley D, Stape JL (2016) Eucalyptus plantation effects on soil carbon after 20 years and three rotations in Brazil. For Ecol Manag 359:92-98. doi:10.1016/j.foreco.2015.09.035

Danjon F, Reubens B (2008) Assessing and analyzing 3D architecture of woody root systems, a review of methods and applications in tree and soil stability, resource acquisition and allocation. Plant Soil 303: 1-34. doi:10.1007/s11104-007-9470-7

De Schrijver A, Vesterdal L, Hansen K, De Frenne P, Augusto L, Achat DL, Staelens J, Baeten L, De Keersmaeker L, De Neve S, Verheyen K (2012) Four decades of post-agricultural forest development have caused major redistributions of soil phosphorus fractions. Oecologia 169:221-234. doi:10.1007/s00442-011-2185-8

Du H, Zeng FP, Peng WX, Wang KL, Zhang H, Liu L, Song TQ (2015) Carbon storage in a eucalyptus plantation chronosequence in southern China. Forests 6:1763-1778. doi:10.3390/f6061763

F.R.A. (2015) Rapport d'évaluation des ressources forestières au Maroc. FAO, Roma

FAO/IUSS (2006) World reference base for soil resources: a framework for international classification, correlation and communication. FAO, Rome

Ferreira V, Koricheva J, Pozo J, Graca MAS (2016) A meta-analysis on the effects of changes in the composition of native forests on litter decomposition in streams. For Ecol Manag 364:27-38. doi:10.1016/ j.foreco.2016.01.002

Gomez-Garcia E, Dieguez-Aranda U, Cunha M, Rodriguez-Soalleiro R (2016) Comparison of harvest-related removal of aboveground biomass, carbon and nutrients in pedunculate oak stands and in fastgrowing tree stands in NW Spain. For Ecol Manag 365:119-127. doi:10.1016/j.foreco.2016.01.021

González-García M, Hevia A, Majada J, Rubiera F, Barrio-Anta M (2015) Nutritional, carbon and energy evaluation of Eucalyptus nitens short rotation bioenergy plantations in northwestern Spain. Iforest 9:303-310. doi:10.3832/ifor1505-008

Guo LB, Gifford RM (2002) Soil carbon stocks and land use change: a meta analysis. Glob Chang Biol 8:345-360. doi:10.1046/j.13541013.2002.00486.x

Hatton PJ, Castanha C, Torn MS, Bird JA (2015) Litter type control on soil $\mathrm{C}$ and $\mathrm{N}$ stabilization dynamics in a temperate forest. Glob Chang Biol 21:1358-1367. doi:10.1111/gcb.12786

Hernández J, del Pino A, Hitta M, Lorenzo M (2016a) Management of forest harvest residues affects soil nutrient availability during reforestation of Eucalyptus grandis. Nutr Cycl Agroecosyst 105:141155. doi:10.1007/s10705-016-9781-2
Hernández J, del Pino A, Vance ED, Califra Á, Del Giorgio F, Martínez L, González-Barrios P (2016b) Eucalyptus and Pinus stand density effects on soil carbon sequestration. For Ecol Manag 368:28-38. doi:10.1016/j.foreco.2016.03.007

Herrero C, Juez L, Tejedor C, Pando V, Bravo F (2014) Importance of root system in total biomass for Eucalyptus globulus in northern Spain. Biomass Bioenergy 67:212-222. doi:10.1016/j.biombioe. 2014.04.023

Hopmans P, Stewart HTL, Flinn DW (1993) Impacts of harvesting on nutrients in a eucalypt ecosystem in southeastern Australia. For Ecol Manag 59:29-51. doi:10.1016/0378-1127(93)90069-Y

Hracherrass A, Berkat O, Ismaili M, De Montard FX (2013) Symbiotic fixation of nitrogen by Genista linifolia: influences of soil depth and tree cover in the cork oak forest of Mamora, Morocco [in French]. Cahiers Agric 22:124-132. doi:10.1684/agr.2013.0614

Jeddi K, Cortina J, Chaieb M (2009) Acacia salicina, Pinus halepensis and Eucalyptus occidentalis improve soil surface conditions in arid southern Tunisia. J Arid Environ 73:1005-1013. doi:10.1016/j. jaridenv.2009.05.005

Johnson CE (2002) Cation exchange properties of acid forest soils of the northeastern USA. Eur J Soil Sci 53:271-282. doi:10.1046/j.13652389.2002.00441.x

Laclau JP, Bouillet JP, Ranger J (2000) Dynamics of biomass and nutrient accumulation in a clonal plantation of eucalyptus in Congo. For Ecol Manag 128:181-196. doi:10.1016/S0378-1127(99)00146-2

Laclau JP, Arnaud M, Bouillet JP, Ranger J (2001) Spatial distribution of eucalyptus roots in a deep sandy soil in the Congo: relationships with the ability of the stand to take up water and nutrients. Tree Physiol 21:129-136. doi:10.1093/treephys/21.2-3.129

Laclau JP, Deleporte P, Ranger J, Bouilleti JP, Kazotti G (2003) Nutrient dynamics throughout the rotation of eucalyptus clonal stands in Congo. Ann Bot 91:879-892. doi:10.1093/aob/mcg093

Laclau JP, Ranger J, Goncalves JLD, Maquere V, Krusche AV, M'Bou AT, Nouvellon Y, Saint-Andre L, Bouillet JP, Piccolo MD, Deleporte P (2010) Biogeochemical cycles of nutrients in tropical eucalyptus plantations: main features shown by intensive monitoring in Congo and Brazil. For Ecol Manag 259:1771-1785. doi:10.1016/j. foreco.2009.06.010

Lakrikba EM (2015) The prevention of flood risks using land management in Morocco [in French]. Master report. Univ, Laval, 135 p

Lamarque JF, Kiehl JT, Brasseur GP, Butler T, Cameron-Smith P, Collins WD, Collins WJ, Granier C, Hauglustaine D, Hess PG, Holland EA, Horowitz L, Lawrence MG, McKenna D, Merilees P, Prather MJ, Rasch PJ, Rotman D, Shindell D, Thornton P (2005) Assessing future nitrogen deposition and carbon cycle feedback using a multimodel approach: analysis of nitrogen deposition. J Geophys Res Atmos 110:1-21. doi:10.1029/2005JD005825

Laouina A, Aderghal M, Al Karkouri J, Antari M, Chaker M, Laghazi Y, Machmachi J, Machouri N, Nafaa R, Naimi K, Nouira A, Sfa M (2010) The efforts for cork oak forest management and their effects on soil conservation. Forest Syst 19:263-277. doi:10.5424/fs/ 2010192-01320

Leite FP, Silva IR, Novais RF, de Barros NF, Neves JCL (2010) Alterations of soil chemical properties by eucalyptus cultivation in five regions in the Rio Doce valley. Rev Bras Cienc Solo 34:821831. doi:10.1590/S0100-06832010000300024

Lemenih M, Olsson M, Karltun E (2004) Comparison of soil attributes under Cupressus lusitanica and Eucalyptus saligna established on abandoned farmlands with continuously cropped farmlands and natural forest in Ethiopia. For Ecol Manag 195:57-67. doi:10.1016/j. foreco.2004.02.055

Li DJ, Niu SL, Luo YQ (2012) Global patterns of the dynamics of soil carbon and nitrogen stocks following afforestation: a meta-analysis. New Phytol 195:172-181. doi:10.1111/j.1469-8137.2012.04150.x

Michelsen A, Lisanework N, Friis I (1993) Impacts of tree plantations in the Ethiopian highland on soil fertility, shoot and root-growth, 
nutrient utilization and mycorrhizal colonization. For Ecol Manag 61:299-324. doi:10.1016/0378-1127(93)90208-5

Nogueira MA, Albino UB, Brandao-Junior O, Braun G, Cruz MF, Dias BA, Duarte RTD, Gioppo NMR, Menna P, Orlandi JM, Raimam MP, Rampazo LGL, Santos MA, Silva MEZ, Vieira FP, Torezan JMD, Hungria M, Andrade G (2006) Promising indicators for assessment of agroecosystems alteration among natural, reforested and agricultural land use in southern Brazil. Agric Ecosyst Environ 115: 237-247. doi:10.1016/j.agee.2006.01.008

Olsen SR, CV Cole, FS Watanabe, LA Dean (1954) Estimation of available phosphorus in soils by extraction with NaHCO3. US Department of Agriculture Circular, 939

Oubrahim H (2015) Estimation and mapping of carbon stocks in the Quercus suber ecosystem of the Western Mamora forest [in French]. $\mathrm{PhD}$ report, University Mohammed V.

Oubrahim H, Boulmane M, Bakker MR, Augusto L, Halim M (2016) Carbon storage in degraded cork oak (Quercus suber) forests on flat lowlands in Morocco. Iforest 9:125-137. doi:10.3832/ifor1364-008

Paul KI, Polglase PJ, Nyakuengama JG, Khanna PK (2002) Change in soil carbon following afforestation. For Ecol Manag 168:241-257. doi:10.1016/S0378-1127(01)00740-X

Pinheiro RC, de Deus JC, Nouvellon Y, Campoe OC, Stape JL, Aló LL, Guerrini IA, Jourdan C, Laclau JP (2016) A fast exploration of very deep soil layers by eucalyptus seedlings and clones in Brazil. For Ecol Manag 366:143-152. doi:10.1016/j.foreco.2016.02.012

Poeplau C, Don A, Vesterdal L, Leifeld J, Van Wesemael B, Schumacher J, Gensior A (2011) Temporal dynamics of soil organic carbon after land-use change in the temperate zone - carbon response functions as a model approach. Glob Chang Biol 17:2415-2427. doi:10.1111/ j.1365-2486.2011.02408.x

Poore MED, C Fries (1986) The ecological effects of eucalyptus. FAO, Forestry paper number 59, $125 \mathrm{p}$.

Razakamanarivo RH, Razakavololona A, Razafindrakoto MA, Vieilledent G, Albrecht A (2012) Below-ground biomass production and allometric relationships of eucalyptus coppice plantation in the central highlands of Madagascar. Biomass Bioenergy 45:1-10. doi: 10.1016/j.biombioe.2011.01.020

Reed SC, Cleveland CC, Townsend AR (2011) Functional ecology of free-living nitrogen fixation: a contemporary perspective. Annu Rev Ecol Evol Syst 42:489-512. doi:10.1146/annurev-ecolsys102710-145034

Ritson P, Sochacki S (2003) Measurement and prediction of biomass and carbon content of Pinus pinaster trees in farm forestry plantations, south-western Australia. For Ecol Manag 175:103-117. doi:10. 1016/S0378-1127(02)00121-4

Rocha JHT, de Moraes Gonçalves JL, Gava JL, de Oliveira Godinho T, Melo EA, Bazani JH, Hubner A, Arthur JC, Wichert MP (2016) Forest residue maintenance increased the wood productivity of a eucalyptus plantation over two short rotations. For Ecol Manag 379:1-10. doi:10.1016/j.foreco.2016.07.042

Salomon R, Rodriguez-Calcerrada J, Zafra E, Morales-Molino C, Rodriguez-Garcia A, Gonzalez-Doncel I, Oleksyn J, Zytkowiak R, Lopez R, Miranda JC, Gil L, Valbuena-Carabana M (2016) Unearthing the roots of degradation of Quercus pyrenaica coppices: a root-to-shoot imbalance caused by historical management? For Ecol Manag 363:200-211. doi:10.1016/j.foreco.2015.12.040

Seifan M (2009) Long-term effects of anthropogenic activities on semiarid sand dunes. J Arid Environ 73:332-337. doi:10.1016/j.jaridenv. 2008.10.009

Singh B, Tripathi KP, Jain RK, Behl HM (2000) Fine root biomass and tree species effects on potential $\mathrm{N}$ mineralization in afforested sodic soils. Plant Soil 219:81-89. doi:10.1023/A:1004720826347

Sullivan S, Rohde R (2002) On non-equilibrium in arid and semi-arid grazing systems. J Biogeogr 29:1595-1618. doi:10.1046/j.13652699.2002.00799.x

Tang CQ, Hou XL, Gao K, Xia TY, Duan CQ, Fu DG (2007) Man-made versus natural forests in mid-Yunnan, southwestern China: plant diversity and initial data on water and soil conservation. Mt Res Dev 27:242-249. doi:10.1659/Mrd.0732

Temesgen D, Gonzálo J, Turrión MB (2016) Effects of short-rotation Eucalyptus plantations on soil quality attributes in highly acidic soils of the central highlands of Ethiopia. Soil Use Manag 32:210-219. doi:10.1111/sum.12257

Turner J, Lambert M (2016) Pattern of carbon and nutrient cycling in a small eucalyptus forest catchment, NSW. For Ecol Manag 372:258 268. doi:10.1016/j.foreco.2016.04.012

Turpault MP, Bonnaud P, Fichter J, Ranger J, Dambrine E (1996) Distribution of cation exchange capacity between organic matter and mineral fractions in acid forest soils (Vosges mountains, France). Eur J Soil Sci 47:545-556. doi:10.1111/j.1365-2389. 1996.tb01854.x

Vega-Nieva DJ, Valero E, Picos J, Jimenez E (2015) Modeling the above and belowground biomass of planted and coppiced Eucalytpus globulus stands in NW Spain. Ann For Sci 72:967-980. doi:10. 1007/s13595-015-0493-6

Villamil MB, Amiotti NM, Peinemann N (2001) Soil degradation related to overgrazing in the semi-arid southern Caldenal area of Argentina. Soil Sci 166:441-452. doi:10.1097/00010694-200107000-00002

Vörösmarty CJ, Sahagian D (2000) Anthropogenic disturbance of the terrestrial water cycle. Bioscience 50:753-765. doi:10.1641/00063568(2000)050[0753:Adottw]2.0.Co;2

Walkley A, Black IA (1934) An examination of the Degtjareff method for determining soil organic matter, and a proposed modification of the chromic acid titration method. Soil Sci 37:29-38. doi:10.1097/ 00010694-193401000-00003

Wei XR, Shao MG, Gale W, Li LH (2014) Global pattern of soil carbon losses due to the conversion of forests to agricultural land. Sci Rep 4: 4062. doi:10.1038/srep04062

Zadworny M, Jagodzinski AM, Lakomy P, Ufnalski K, Oleksyn J (2014) The silent shareholder in deterioration of oak growth: common planting practices affect the long-term response of oaks to periodic drought. For Ecol Manag 318:133-141. doi:10.1016/j.foreco.2014. 01.017

Zhang YG, Xiao M, Dong YH, Jiang Y (2012) Determination of soil exchangeable base cations by using atomic absorption spectrophotometer and extraction with ammonium acetate. Spectrosc Spectr Anal 32:2242-2245. doi:10.3964/j.issn.1000-0593(2012)08-224204 